\title{
MANAJEMEN PROSES KONVERSI PERBANKAN KONVENSIONAL MENJADI PERBANKAN SYARIAH STUDI KASUS BANK NTB SYARIAH
}

\author{
${ }^{1}$ Andi Nurmansyah Ramdan, ${ }^{2^{*}}$ Radyum Ikono, ${ }^{3 *}$ Putri Reno Kemala Sari
}

1Sekolah Pascasarjana Universitas Teknologi Sumbawa

${ }^{2}$ Fakultas Teknik Universitas Teknologi Sumbawa

${ }^{3}$ Fakultas Ekonomi dan Bisnis Universitas Teknologi Sumbawa

“Corresponding Author email: rikono@nano.or.id \& putri.reno.kemala.sari@uts.ac.id

\section{Diterima: \\ Bulan Juni 2020}

\section{Diterbitkan:}

Bulan Juli 2020

Keyword:

Manajemen, Konversi, Inovasi, Perbankan

Konvensional,

Perbankan Syariah.

\begin{abstract}
Abstrak
Perkembangan keuangan syariah di Indonesia yang sangat pesat dibuktikan dengan berhasil meraih Global Islamic Financial Report (GIFR) Award 2019. Perkembangan industri perbankan syariah disambut baik oleh para pengguna jasa perbankan, khususnya daerah provinsi Nusa Tenggara Barat (NTB) dengan berhasilnya Bank Pembangunan Daerah (BPD) NTB melakukan konversi menjadi Bank NTB Syariah pada tanggal 4 September 2018, konversi ini merupakan inovasi besar dalam perbankan Indonesia. Penelitian ini bertujuan untuk mengetahui manajemen proses yang dilakukan Bank NTB Syariah dalam mengendalikan Sumber Daya Manusia pada setiap tahap konversi sesuai dengan model perubahan Lewin. Penelitian ini merupakan penelitian kualitatif yang bersifat deskriptif dengan pendekatan studi kasus pada konversi Bank NTB Syariah. Sumber data yang digunakan adalah data primer dan sekunder yaitu dengan teknik wawancara, studi pustaka, studi dokumentasi, dan internet searching. Hasil dari penelitian ini menyimpulkan bahwa proses konversi Bank NTB Syariah berjalan dengan baik. Manajemen proses dilakukan dengan kehati-hatian dan mempertimbangkan persiapan dan pelaksanaan, pengembangan SDI, performa Bank NTB Syariah, serta mendokumentasi yang baik. Pada setiap tahap konversi harus selalu memotivasi SDI yang ada agar tetap berada pada sistem konversi yang diinginkan dengan cara melaksanakan pelatihan, melakukan Benchmark dan menjalin kerja sama dengan lembaga-lembaga lainnya. Pasca konversi Bank NTB Syariah mengalami peningkatan kinerja yang signifikan, dengan peningkatan potret DPK yang sangat signifikan, yaitu sebesar kurang lebih $40 \%$ rata-rata pertumbuhan setiap tahunnya.
\end{abstract}

\section{PENDAHULUAN}

Indonesia merupakan negara dengan jumlah penduduk Muslim mencapai 87,18 persen dari populasi 232,5 juta jiwa (Global Islamic Economy Report 2018-2019). Menurut Badan Perencanaan dan Pembangunan Nasional dalam Masterplan Ekonomi Syariah Indonesia, mayoritas muslim di Indonesia merupakan ukuran pangsa pasar produk dan jasa berbasis ekonomi syariah yang sangat besar. Fokus utama implementasi pengembangan ekonomi syariah adalah sektor riil, Perbankan merupakan lembaga pembiayaan bagi sektor riil untuk meningkatkan produktivitasnya. Menurut Marimin, dkk (2015) kehadiran dan fungsi perbankan di Indonesia mempunyai peranan dan pengaruh yang sangat signifikan, baik untuk masyarakat maupun industri besar, menengah ataupun bawah. Sistem perbankan di Indonesia terdapat dua macam sistem operasional perbankan, yaitu bank konvensional dan bank syariah. Marimin, dkk (2015) menjelaskan bahwa dalam mengantisipasi kebutuhan masyarakat serta memberikan rasa aman dan nyaman dalam transaksi perbankan, kehadiran Bank Syariah merupakan salah satu solusi untuk menambah kepercayaan masyarakat terhadap kegiatan perbankan khususnya di Indonesia. Putri dan Dharma (2016) juga menegaskan kehadiran bank syariah dilakukan untuk mengantisipasi tantangan system keuangan yang semakin maju dan kompleks.

Indonesia sebagai negara berpenduduk Muslim terbesar di dunia masih dalam proses mencari bentuk untuk mengembangkan sistem keuangan syariah, namun geliat minat ekonomi syariah di dalam negeri semakin semarak dan ini tentunya menjadi modal sosial untuk memperbesar market share-nya di masa mendatang (Rama, 2015). Menurut Ria (2004) perkembangan bank syariah baik yang merupakan hasil konversi atau bukan mengalami perkembangan yang sangat signifikan dibandingkan dengan sebelum dikeluarkannya peraturan mengenai landasan operasional bank syariah dan mengenai proses pelaksanaan konversi bank. Kemudian beberapa tahun belakangan ini, pembicaraan tentang lembaga keuangan islam 
terutama perbankan syariah sangat marak, hal ini disebabkan pertumbuhan perbankan syariah di Indonesia dianggap sangat cepat (Toin, 2014). Sejalan dengan Purba (2017) yang menjelaskan bahwa pertumbuhan perbankan saat ini bisa dikatakan tumbuh dengan pesat, khususnya perbankan syariah yang merupakan lembaga keuangan yang berlandaskan syariah atau hukum islam. Bahkan pada tahun 2019 Indonesia meraih Global Islamic Financial Report (GIFR) Award 2019, karena berdasarkan rujukan dari Islamic Financial Country Index 2019, Indonesia berada pada posisi pertama dari 44 negara dengan skor 81,93 .

Grafik perkembangan kinerja bank umum konvensional dan bank umum syariah (\%)

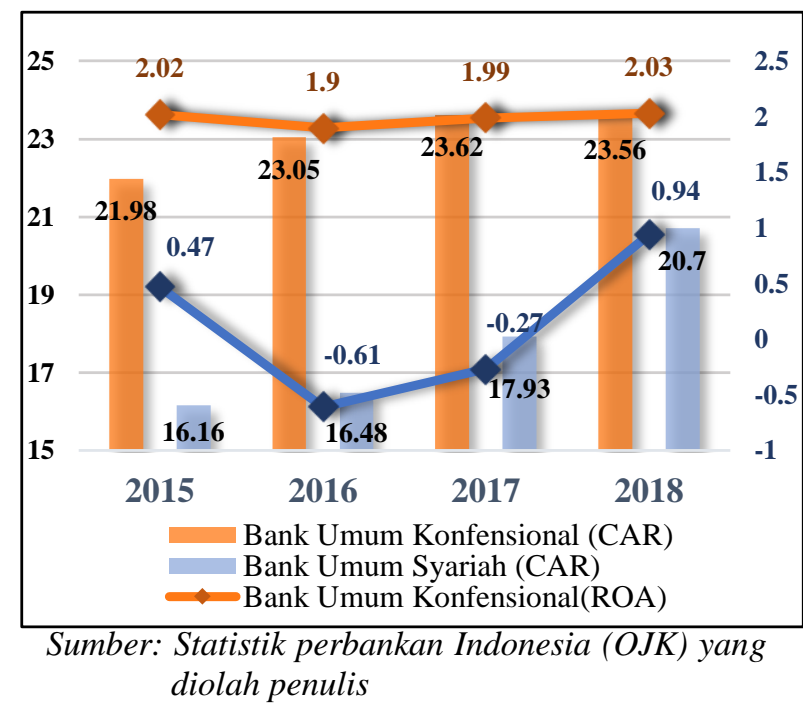

Dari gambar diatas dapat dilihat bahwa perkembangan kinerja perbankan syariah dari tahun 2015 hingga tahun 2018 lebih meningkat dibandingkan dengan kinerja perbankan konvensional dalam tahun yang sama, namun apabila dilihat dari jumlah persentase Capital Adequaci Ratio (CAR) dan Return On Asset (ROA) perbankan syariah masih berada di bawah perbankan konvensional. Sama dengan hasil penelitian yang dilakukan oleh Thayib dkk (2017) mengungkapkan bahwa CAR perbankan syariah lebih baik dari pada perbankan konvensional namun ROA antara bank syariah dan konvensional tidak memiliki perbedaan yang signifikan. Dengan potensi penduduk Indonesia yang bermayoritas muslim bahkan merupakan terbesar di dunia seharusnya memiliki kinerja produk syariah yang lebih baik. Hal ini sesuai dengan hasil penelitian yang dilakukan oleh Handayani, dkk (2018) menunjukkan bahwa keyakinan, komitmen dan sikap seseorang yang didasari nilai-nilai agama diyakini menjadi prediktator kuat yang akan mengarahkan perilaku individu dalam melakukan pembelian atau menggunakan jasa perbankan syariah. Begitu juga dengan Zuhirsyan dan Nurlinda (2018) yang menyimpulkan bahwa religiusitas dan persepsi nasabah berpengaruh secara signifikan terhadap keputusan memilih bank syariah.

Di Indonesia sendiri perkembangan industri perbankan syariah disambut baik oleh para pengguna jasa perbankan, terutama di Provinsiprovinsi yang mayoritas masyarakatnya menganut agama islam, salah satunya ialah Provinsi Nusa Tenggara Barat (NTB). Pada tanggal 4 September 2018, Bank Pembangunan Daerah Nusa Tenggara Barat resmi beroperasi secara penuh sebagai Bank NTB Syariah. Bank NTB Syariah merupakan Bank Pembangunan Daerah (BPD) kedua yang melakukan konversi, setelah sebelumnya Bank Aceh berhasil konversi menjadi Bank Aceh Syariah pada tahun 2017. Konversi yang dilakukan oleh Bank NTB Syariah telah meningkatkan aset perbankan syariah di Indonesia sebesar 7,26 Triliun (OJK, 2018). Sunaryo (2017) menjelaskan bahwa perubahan organisasi mempunyai manfaat bagi kelangsungan hidup suatu organisasi, karena tanpa adanya perubahan dapat dipastikan bahwa usia organisasi itu tidak akan bertahan lama. Sejalan dengan penjelasan Simbolon dan Hastin (2013) mengemukakan esensi dari suatu perubahan adalah peningkatan kondisi yang lebih baik dari situasi sebelumnya, dan suatu organisasi akan bertahan jika dapat melakukan perubahan. Sehingga konversi Bank NTB Syariah ini diharapkan dapat meningkatkan kondisi organisasi dan menjadi pilihan, khususnya bagi masyarakat NTB dalam memilih jasa perbankan tanpa harus khawatir dengan permasalahan riba.

Proses konversi yang dilakukan Bank NTB Syariah pasti memiliki motivasi yang besar serta hambatan dan tantangan dalam setiap tahap yang dilalui, dari tahap perencanaan, tahap perubahan hingga tahap awal pengaplikasian perubahan yang direncanakan. Karena menurut Syafii (2016), ada banyak faktor yang mendesak melakukan konversi dari bank konvensional menjadi bank syariah. Sejalan dengan Wijaya (2017), jika perubahan besar itu terjadi, tidak dipungkiri perubahan tersebut dibengaruhi oleh beberapa faktor, baik faktor positif yang mendukung organisasi tersebut menjadi maju ataupun faktor negatif yang membuat organisasi mundur. Konversi Bank Pembangunan Daerah NTB menjadi Bank NTB Syariah merupakan inovasi besar untuk meningkatkan perekonomian yang berbasis syariah di tingkat daerah, nasional bahkan internasional. Dari penjelasan diatas penulis ingin menganalisa bagaimana bank NTB Syariah melakukan proses manajemen pengendalian sumber daya manusia dalam setiap tahap konversi. 


\section{LANDASAN TEORI}

\section{Model Perubahan Lewin}

Model pengelolaan dalam sebuah perubahan organisasi yang diungkapkan pertama kali oleh Kurt Lewin, dikenal dengan konsep forcefield yang diartikan sebagai model power-based, hal ini karena menekankan kekuatan-kekuatan penekanan yang terjadi selama proses perubahan, dalam setiap proses perubahan akan terdapat kekuatan-kekuatan yang mendukung dan kekuatankekuatan yang tidak mendukung bahkan menolak perubahan tersebut (Fanggidae, dkk., 2015). Ada tiga tahap yang telah dikembangkan oleh Kurt Lewin sebagai model perubahan yaitu meliputi bagaimana mengambil inisiatif perubahan, kemudian mengelola dan menyetabilkan proses perubahan. Robbins dalam Wijaya (2017: 253) menjelaskan tahap perubahan tersebut dengan istilah unfreezing, Moving \& refreezing. Menurutnya Unfreezing diartikan sebagai proses awal dalam tahap perubahan. Pada tahap unfreezing ini terjadi pencairan atau peleburan perilaku dari sistem yang akan ditinggalkan (status quo). Kemudian moving merupakan sebuah tahap transisi dan pembelajaran. Pada tahap ini, segala sumber daya manusia akan diberikan informasi yang baru mengenai model dan sistem kerja yang diharapkan dapat diterapkan secara maksimal, diartikan juga sebagai cara pandang baru untuk level pengambil kebijakan. Ketiga adalah Refreezing yang merupakan sebuah tahap pembekuan kembali atau pemantapan perilaku, sistem, serta cara pandang. Pada tahap refreezing diperlukan sebuah peneguhan dan penegasan kembali tentang tujuan perubahan yang sedang dijalankan untuk menghasilkan perubahan yang sesuai dengan tujuan awal yang telah disepakati bersama.

\section{Konversi Perbankan}

Definisi perubahan sebuah organisasi pada dasarnya tidak akan terlepas dari reorganisasi dan perubahan organisasi itu sendiri (Sunaryo, 2017). Sejalan dengan penjelasan Simbolon dan Hastin (2013), sasaran utama perubahan dalam organisasi terdiri dari perubahan sikap dan keterampilan kerja, perubahan peran kerja, perubahan teknologi dan perubahan strategi. Perubahan itu sendiri disebabkan karena kebutuhan proses yang lebih baik, perubahan struktur industri atau pasar, perubahan persepsi, perubahan peraturan dan perubahan pengetahuan yang tentunya mengarah pada hal yang baru serta menimbulkan makna baru (Rahayuningsih, 2018). Sama dengan kegiatan konversi Bank NTB Syariah dituntut oleh keadaan kelompok masyarakat, sehingga kegiatan konversi bank konvensional menjadi bank syariah harus didukung agar dapat terbentuk kondisi perubahan perbankan konvensional menjadi syariah yang konsisten dan kuat dalam menerapkan segala prinsip-prinsip syariah, akan tetapi dalam pelaksanaan perubahan tetap mengharuskan memperhatikan asas perbankan yang sehat dan prinsip kehati-hatian.

\section{Perbankan Konvensional dan Perbankan Syariah}

Bank berasal dari kata Itali, yaitu banco yang artinya bangku, bangku inilah yang dipergunakan oleh bank untuk melayani beberapa kegiatan dalam melakukan operasionalnya kepada orang yang memerlukan jas keuangan perbankan. Kemudian istilah bangku secara resmi dan popular menjadi bank. Menurut PSAK (Pernyataan Standar Akuntansi Keuangan) No.31, Bank merupakan lembaga yang berperan sebagai lembaga keuangan antara pihak-pihak yang memiliki dana lebih dan pihak-pihak yang membutuhkan dana, serta lembaga-lembaga yang mendukung lalu lintas pembayaran. Awal dari perkembangan perbankan di Indonesia adalah perbankan diartikan sebagai badan usaha yang menghimpun dana dari masyarkat dalam bentuk simpanan kemudian menyalurkan kembali kepada masyarakat dengan tujuan meningkatkan taraf hidup rakyat banyak (Marimin, 2015). Berdasarkan Undang-undang Nomor 10 Tahun 1998 bank konvensional yaitu bank yang melakukan operasional atau kegiatan usaha secara konvensional yang mana memberikan jasa dalam lalu lintas pembayaran berdasarkan prosedur dan ketentuan yang telah ditetapkan. Menurut Wafa (2017), bank konvensional adalah suatu jenis lembaga keuangan yang memberikan jasa, contohnya antara lain menghimpun dana dari masyarakat, kemudian menyalurkan dana kepada masyarakat dalam bentuk kredit, dan memperlancar transaksi perdagangan dengan menggunakan sistem perhitungan bunya atau interest forgone.

Bank Islam atau bank syariah merupakan bank yang beroperasi tidak dengan menggantungkan pada bunga, bank Islam juga sering disebut dengan bank yang tidak mengandalkan bunga, yaitu lembaga perbankan yang operasionalnya dan produknya dikembangkan berdasarkan pada prinsipprinsip islam yang tertuang di Al-Qur'an dan Hadits Nabi SAW (Wilardjo, 2004). Menurut Wafa (2017) dan Purba (2017), perbankan syariah merupakan lembaga keuangan yang berperan sebagai penghimpun dana serta mengalirkan dana masyarakat, khususnya masyarakat muslim dan menetapkan imbalan atau keuntungan yang berdasarkan pada sistem bagi hasil. Fadilah (2018) juga menjelaskan bahwa perbankan syariah adalah segala sesuatu yang menyangkut tentang bank syariah, baik bank umum syariah maupun unit usaha syariah yang termasuk tentang kelembagaan, kegiatan usaha bank, serta semua cara dan proses 
dalam melakukan kegiatan atau operasional usaha perbankan. Kemudian industri perbankan syariah juga memiliki ciri atau karakteristik umum yang terdapat pada industri perbankan, yaitu industri yang padat dan ketat dengan regulasi dan industri yang berdasarkan kepercayaan kepada Allah SWT (Apriyanti, 2017).

\section{Inovasi}

Inovasi pertama kali diperkenalkan oleh Scumpeter pada tahun 1934, inovasi dilihat sebagai kreasi dan implementasi dari suatu rangkaian yang baru, kemudian istilah rangkaian baru ini dapat merujuk pada jasa, produk, proses kerja, pasar, kebijakan dan sistem baru (Helmi, 2009). Menurut Stata dalam Sumuel (2018) menyatakan bahwa istilah inovasi erat kaitannya dengan teknologi yang berfungsi untuk membuka wawasan sebuah perusahaan tentang suatu produk baru atau meningkatkan desain serta manufaktur dari produk atau jasa yang sudah ada pada perusahaan. Nurjannah (2015) menjelaskan bahwa inovasi muncul ketika kreatifitas dan knowledge disatukan dalam sebuah karya baik prosesnya maupun hasilnya. Inovasi juga merupakan suatu proses kolaborasi antara kreatifitas dan pengetahuan yang merupakan hasil pengembangan dan pemanfaatan suatu produk atau sumber daya yang telah ada sebelumnya, kemudian dapat memiliki nilai yang lebih berarti. Kemajuan teknologi dan ilmu pengetahuan sangat mempengaruhi proses inovasi karena kedua hal tersebut dapat memberikan memudahkan dalam memproduksi sesuatu hal yang baru dan berbeda. Sehingga pada dasarnya manfaat inovasi itu akan menyempurnakan atau meningkatkan nilai guna atau fungsi dari pemanfaatan suatu produk atau sumber daya yang kemudian manusia dapat mendapatkan manfaat yang lebih. Inovasi ini dapat dikembangkan di berbagai bidang kehidupan, mulai dari bidang bisnis, pendidikan, komunikasi, dan bidang-bidang lainnya.

\section{METODE PENELITIAN}

Penelitian ini merupakan penelitian kualitatif dan bersifat deskriptif. Metode penelitian kualitatif "merupakan penelitian yang berusaha mengkonstruksi realitas dan memahami maknanya, sehingga penelitian kualitatif biasanya sangat memperhatikan proses, peristiwa dan otentisitas" (Somantri, 2005). Peneliti bertindak sebagai instrumen sekaligus pengumpul data dan menjadi pengamat partisipan. Sehingga yang menjadi tujuan dari penelitian kualitatif ini adalah menggambarkan realitas empiris di balik fenomena secara mendalam dan rinci. Penelitian ini menggunakan sumber data pada salah satu perbankan syariah, yaitu Bank Nusa Tenggara Barat (NTB) Syariah, yang menggunakan pendekatan studi kasus, karena mengarah pada konversi Bank NTB Syariah yang dilakukan pada bulan September 2018 untuk menganalisa proses yang terjadi pada tahap sebelum konversi, proses konversi dan setelah melakukan konversi.

Paradigma kualitatif digunakan karena berdasarkan pada dua alasan, pertama permasalahan yang dikaji dalam penelitian ini membutuhkan sejumlah data lapangan yang bersifat aktual dan konstektual. Kedua, pemilihan pendekatan ini didasarkan pada keterkaitan masalah yang dikaji dan tidak dapat dipisahkan oleh fakta alamiahnya. Pada penelitian ini menggunakan data primer dan data sekunder, data primer merupakan data yang diperoleh dari hasil penelitian lapangan langsung dan data sekunder berupa jurnal dan dokumendokumen di luar data primer yang mendukung penelitian. Kemudian informan penelitian adalah orang atau pelaku yang dibutuhkan untuk memberikan informasi tentang situasi dan kondisi latar belakang penelitian serta merupakan orang yang benar-benar mengetahui permasalahan yang akan diteliti. Informan tersebut antara lain adalah General Manager, Change Manager Office, dan Manager Sumber Daya Manusia (SDI) Bank NTB Syariah. Kemudian dalam menganalisa data kualitatif menggunakan beberapa tahap yaitu:

- Tahap pengupulan data, pada proses ini peneliti dapat menemukan makna dibalik fenomena yang disaksikan.

- Tahap reduksi data, yaitu proses pemilihan, penyederhanaan, dan transformasi data.

- Tahap penyajian data.

- Verifikasi dan penarikan kesimpulan.

\section{HASIL DAN PEMBAHASAN}

\section{Latar Belakang Konversi Bank NTB Syariah}

BPD NTB (Bank Pembangunan Daerah

Nusa Tenggara Barat) adalah bank milik pemerintah provinsi Nusa Tenggara Barat dan Pemerintah Kota/Kabupaten se-Nusa Tenggara Barat. Bank NTB Syariah terbentuk dan mulai beroperasi pada tanggal 5 Juli 1964. Dalam persiapan pendirian Bank NTB Syariah di kembangkan oleh bapak Muhammad Syareh dan kemudian diangkat sebagai Direktur Utama pertama Bank NTB Syariah. Perubahan bentuk hukum Bank Pembangunan Daerah Nusa Tenggara Barat dari Perusahaan Daerah menjadi Perseroan Terbatas (PT) Bank Pembangunan Daerah Nusa Tenggara Barat yaitu dilakukan pada tanggal 19 Maret 1999. Kemudian sesuai dengan hasil keputusan Rapat Umum Pemegang Saham tanggal 13 Juni 2016 yang menyepakati untuk melakukan konversi dari PT Bank Pembangunan Daerah NTB menjadi Bank NTB Syariah dan untuk memberikan harapan baru serta penguatan ekonomi kerakyatan yang berkeadilan di Nusa Tenggara Barat. Adanya 
keputusan tersebut, proses konversi Bank NTB Syariah kemudian dilaksanakan melalui kajian yang panjang, komprehensif dan sesuai dengan ketentuan-ketentuan yang berlaku. Pada tanggal 29 Maret 2018, pihak Bank NTB Syariah mengajukan persyaratan-persyaratan untuk mendapatkan izin perubahan usaha menjadi Bank Umum Syariah kepada pihak Otoritas Jasa Keuangan (OJK). Kemudian Bank NTB Syariah secara resmi memperoleh izin dari OJK untuk melaksanankan kegiatan konversi pada tanggal 04 September 2018.

Bank NTB Syariah secara resmi melakukan kegiatan Operasional (Go Live) yang sesuai dengan prinsip-prinsip syariah pada tanggal 24 September 2018, dengan keputusan anggota Dewan Komisioner Otoritas Jasa Keuangan Nomor: Kep-145/D.03/2018 yaitu tentang Perizinan Perubahan Kegiatan Usaha Bank Umum Konvensional Menjadi Bank Umum Syariah. Bank NTB Syariah melakukan konversi bertujuan untuk menjadi Bank Syariah yang amanah, terkemuka dan pilihan masyarakat, serta memberikan semangat yang lebih bagi Bank NTB Syariah sendiri untuk terus menyediakan layanan perbankan yang berbasis syariah sehingga dapat membantu masyarakat dalam transaksi perbankan syariah serta dapat meningkatkan perekonomian daerah di Nusa Tenggara Barat. Model bisnis yang telah disusun dan dikembangkan Bank NTB Syariah bertujuan untuk dapat mewujudkan visi, misi serta sasaran bisnisnya. Sebagaimana yang tercermin dalam visi yaitu untuk menjadi bank syariah yang amanah, terkemuka dan pilihan masyarakat. Bank NTB Syariah terus tumbuh dan berkembang hingga saat ini telah memiliki kantor dengan jumlah 45 yang terdiri dari 1 kantor pusat, 12 kantor cabang, 23 kantor cabang pembantu dan 9 kantor kas. Dalam meningkatkan kualitas pelayanan, Bank NTB Syariah juga memiliki 202 mesin ATM yang tersebar diseluruh kota/kabupaten se-NTB.

Provinsi Nusa Tenggara Barat merupakan salah satu daerah yang memiliki penduduk mayoritas Muslim, sehingga banyak kegiatankegiatan yang dilakukan oleh masyarakat cenderung mengikuti kebiasaan masyarakat muslim yang bersifat umum. Seperti yang dijelaskan oleh Lakonawa (2013) bahwa agama adalah kekuatan sosial yang paling berpengaruh di dunia, agama yang memiliki populasi yang sangat besar akan dapat berperan dalam menentukan pola kehidupan sosial pada suatu masyarakat. Kemudian Mulyadi (2016) juga menyimpulkan bahwa agama akan sangat berpengaruh dalam kehidupan individu dan kehidupan masyarakat. Begitu juga dengan Bank NTB Syariah yang termotivasi melakukan konversi karena unsur agama secara umum, dan bahkan secara khusus konversi dilakukan juga karena individu tertentu, seperti yang dijelaskan oleh salah satu informan selaku general manager Bank NTB Syariah mengatakan:

"Jadi kebetulan kita punya gubernur pada saat itu kan orang yang agamais, jadi yaitu bagaimana caranya masyarakat ini terhindar dari riba sesuai dengan Al-Baqarah 275. . . disamping itu juga seperti yang saya sampaikan tadi, syariah itu sangat luas dia punya pangsa pasarnya.".

Beberapa faktor yang dijelaskan oleh informan, merupakan motivasi dan latar belakang Bank NTB Syariah melakukan konversi, keberhasilan konversi juga karena kumpulan individu yang memiliki motivasi yang sama menjadi sebuah kelompok penggerak dan dapat memotivasi yang lainnya. Namun secara umum konversi yang dilakukan tentunya sudah mempertimbangkan segala macam faktor pendukung dan faktor penghambat pelaksanaan konversi. Seperti tambahan penjelasan informan:

"Bahkan awal-awal kita konversi itu dulu banyak yang khawatir, bukan hanya dari kalangan orang luar kita, internal kita itu banyak yang khawatir, bisa jalan gak bank ini, masih bisa ndk ada namanya bank NTB, karena kekhawatiran . . . dengan ridho Allah, dengan kekuatan kita bersama dengan ee teman-teman yang ada di bank, jadi, mari kita satukan arah, satu tanda titik arah panah yang harus kita tuju yaitu konversi".

Proses Perencanaan/Peleburan Perilaku (Unfreezing) pada Konversi Bank NTB Syariah

Tahap awal sebuah perubahan adalah perencanaan, yaitu aktivitas-aktivitas yang menjadi awal sebuah perubahan akan berjalan dengan lancar dan sukses seperti yang diinginkan. Pada tahap ini terjadi pencairan perilaku dari sistem yang lama dan banyak terjadi pertentangan, namun orang-orang di Bank NTB Syariah memiliki tujuan yang sama untuk mengikuti keputusan yang disepakati pemegang saham, sehingga kekuatan pendorong perubahan mendominasi. Arahan dari pemegang saham dalam melaksanakan konversi agar memperhatikan beberapa hal, yaitu:

- Persiapan dan pelaksanaan konversi dengan benar-benar dilaksanakan secara menyeluruh dan total sesuai prinsip Good Corporate Governance.

- Dalam pengembangan Sumber Daya Insani (SDI), harus memberikan kesempatan yang sama kepada seluruh karyawan/karyawati baik muslim maupun non muslim yang memiliki integritas dan kompetensi yang baik untuk tetap berkarir di Bank NTB Syariah.

- Performa Bank NTB yang sudah baik agar tetap dijaga apabila melakukan konversi dan menjadi lebih baik lagi.

- Pelaksanaan konversi agar didokumentasikan dengan baik agar bisa menjadi rujukan bagi bank lainnya yang akan melakukan konversi. 
Konversi yang dilakukan Bank NTB Syariah pada tahap Unfreezing memerlukan banyak persiapan, hingga menghabiskan waktu kurang lebih dua tahun, sampai benar-benar Bank NTB Syariah siap melakukan Konversi. Tahap awal konversi, pihak Bank NTB Syariah membentuk Tim Project Management (TPM) untuk pelaksanaan konversi, TPM ini tersusun atas Penasehat, Penanggungjawab dan Koordinator. Bidang-bidang yang dipersiapkan oleh TMP yaitu:

- Bidang SDI dan Training

- Bidang Akuntansi dan Pelaporan

- Bidang Perizinan, Organisasi dan Edukasi

- Bidang Pengembangan Produk, Jasa, dan Operation Syariah

- Bidang Perencanaan Strategis (Bussiness Plan dan Corporate Plan)

- Bidang Infrastruktur IT

- Bidang Pengembangan IT Konversi/Syariah

- Bidang Pengamanan Peralihan Aset Bisnis dan Liabitities.

- Bidang Mapping SOP Konversi

- Bidang Pembuatan Pedoman/SOP BUS

- Bidang Legal Corporate dan Legal Product Setelah membentuk Tim Project Management, tahap selanjutnya adalah melakukan kerja sama dengan lembaga yang kompeten dalam konversi perbankan, yaitu Lembaga Pengembangan Perbankan Indonesia (LPPI). Pertemuan direksi Bank NTB Syariah dan direksi LPPI, membahas pilihan-pilihan peningkatan kompetensi SDI yang ada di Bank NTB Syariah, seperti bonafiditas kelembagaan, instruktur praktisi aktif di perbankan syariah dan materi training disusun sesuai kebutuhan. Program Customize Training (PCT) dilakukan dalam empat bagian, bagian pertama yaitu kepada stakeholder seperti Gubernur Nusa Tenggara Barat, Bupati/Walikota se-NTB, Pengurus dan DPS. Kedua kepada Pejabat Eksekutif seperti Pimpinan Divisi, PinDesk, Pimpinan Cabang, dan Sub Divisi yang setara. Pada bagian yang ketiga ditujukan kepada pejabat lainnya seperti Wapincab, Pincapem, Penyelia, Analis, Auditor, KIC, Yuris, Dealer, dan lainnya yang setara. Kemudian training diberikan pada bagian keempat adalah pegawai lainnya seperti asisten administrasi, back office, taller, Customer Service (CS) dan lainnya yang setara.

Kemudian Program yang dilakukan untuk mempersiapkan konversi adalah program internship (Benchmark) ke Bank Syariah Mandiri (BSM) yang dilakukan secara bertahap. Internship dibagi menjadi tiga bagian, yaitu Operasional Treasury Syariah (direksi, divisi TRS dan staf) dilakukan ke kantor pusat BSM, Analis Pembiayaan (pincab, pincapem, dan analis kredit produktif) dilakukan ke BSM kantor yang berada di Surabaya dan Denpasar, dan bagian Front Liner (pincab, pincapem, teller dan customer service) yang dilakukan di kantor cabang BSM se-NTB. Dalam memaksimalkan kemampuan sumber daya insani (SDI), Bank NTB Syariah juga melakukan kerjasama dengan konsultan Dunamis Human Capital, untuk menyusun roadmap dan blueprint human capital, revalidasi visi, misi dan nilai budaya perusahaan serta menyusun man power planning.

Kegiatan-kegiatan yang dilakukan dalam tahap perencanaan konversi sangat fokus pada peningkatan kemampuan SDI dan dilakukan secara berkelanjutan, hal ini dilakukan karena sumber daya insani (SDI)-lah yang akan mengaplikasikan, mencerminkan dan mengembangkan prinsip-prinsip syariah dalam setiap aktivitas Bank NTB Syariah. Seperti penjelasan informan selaku general manager untuk change management officce:

"Kita tidak mungkin, yaa, kita tidak mungkin memasarkan prinsip syariah kalau diri kita juga tidak tau, apa itu prinsip-prinsip syariah, jadi itu dimulai dari kita, kita harus punya ilmu itu, kita harus meningkatkan kompetensi kita terkait dengan prinsip syariah, mau tidak mau, suka tidak suka, yaa, karena akhirnya masyarakat pasti akan menanyakan kepada pegawai Bank NTB, bukan kepada siapa-siapa”.

\section{Proses Transisi (Moving) pada Konversi Bank NTB Syariah}

Proses yang kedua dalam melakukan perubahan atau konversi adalah proses transisi, proses pembelajaran atau proses perubahan (moving). Pada tahap ini semua sumber daya insani yang ada akan mengimplementasikan informasi baru, cara pandang baru, serta model atau sistem kerja yang baru. Begitu juga dengan konversi Bank NTB Syariah pada tahap moving, seluruh SDI yang ada harus merubah semua kegiatannya dengan kegiatan yang berbasis syariah sesuai dengan apa yang telah dipersiapkan pada tahap perencanaan, seperti pelatihan, training dan pemagangan. Untuk memastikan kemampuan SDI selalu baik dalam melakukan kegiatan perbankan yang berbasis syariah, pihak Bank NTB Syariah terus melakukan program pelatihan dan penilaian. Hal tersebut dilakukan agar perilaku dan budaya lama (konvensional) tidak kembali dilakukan.

Bank NTB Syariah menyebut tahap ini sebagai Transformasi Nilai Budaya, nilai budaya yang dimaksud yaitu:

1. Menjalankan amanah dan etika syariah, perilaku

yang terkandung didalamnya adalah

- Jujur dan ikhlas

- Santun dan ramah

- Kompeten dan bertanggungjawab

2. Memiliki integritas dan etos kerja

- Disiplin dan konsisten

- Tangguh dan berdedikasi 
3. Melakukan penyempurnaan yang berkelanjutan

- Kreatif dan inovatif

- Selalu belajar dan mengembangkan diri

4. Melaksanakan sinergitas dalam mencapai tujuan

- Empati dan proaktif

- Produktif dan dinamis

- Harmonis dan menghargai keragaman Langkah-langkah untuk melakukan Transformasi Nilai Budaya pada tahap ini adalah

- Merubah dan memaksimalkan performa Bank NTB Syariah, seperti perubahan logo perusahaan, outlet, fitur produk yang ada serta seluruh pakaian yang digunakan dalam melakukan operasional atau pelayanan.

- Memahami dan mengimplementasikan hal-hal yang terkandung dalam visi, misi, nilai budaya dan perilaku utama dalam bersyariah.

- Optimalisasi fungsi Change Agent, disetiap unit kerja memiliki agen perubahan baik di pusat maupun di cabang, optimalisasi fungsi ini dilakukan dalam rangka memaksimalkan perubahan dari budaya atau perilaku yang lama ke yang baru (syariah).

- Menyusun skala prioritas program transformasi, seperti morning breefing, role play dan role model.

- Merubah tool kit Bank NTB Syariah, baik produk (lending \& funding) maupun jasa berbankan.

- Melakukan penyempurnaan SOP secara berkelanjutan dan sosialisasi SOP internal maupun eksternal.

\section{Proses Pemantapan Perilaku (Refreezing) pada Konversi Bank NTB Syariah}

Refreezing atau pemantapan perilaku merupakan tahap terakhir dalam sebuah perubahan, tahap ini mengupayakan agar budaya atau perilaku baik individu maupun kelompok yang telah berubah tidak kembali kepada budaya atau perilaku yang lama. Aktivitas operasional yang dilakukan Bank NTB Syariah setelah melakukan konversi, harus tetap dijaga dan dikembangkan agar selalu mencerminkan perbankan berbasis syariah yang profesional. Pada tahap ini diperlukan sebuah peneguhan dan penegasan kembali secara berkelanjutan tentang arti penting perubahan yang telah dijalankan. Guna mendukung perubahan jangka panjang, tidak hanya budaya dan perilaku yang dimantapkan berbasis syariah tapi secara terus menerus Bank NTB Syariah melakukan pelatihan kepada seluruh SDI yang ada secara berkelanjutan agar dapat meningkatkan performa dan kompetensi yang dimiliki oleh setiap SDI sesuai dengan posisi masing-masing. Kemudian Bank NTB Syariah selalu melakukan penilaian terhadap kinerja SDI yang dilakukan oleh pihak ketiga dan bersifat independen dalam menilai kompetensi dan potensi yang ada pada setiap individu. Penerapan reward dan punishment juga dilakukan secara konsisten dan berjenjang agar menstabilkan kinerja dan memotivasi untuk meningkatkan kinerja dan kompetensi yang dimiliki.

Pasca konversi menjadi perbankan berbasis syariah masih banyak menghadapi tantangan, baik internal maupun eksternal Bank NTB Syariah. Internal-pun setelah melakukan konversi, masih muncul kekhawatiran tentang masa depan Bank NTB Syariah, sehingga seluruh jajaran yang ada, dari manajemen tingkat atas hingga jajaran paling bawah, saling memotivasi untuk tetap yakin dengan keberhasilan konversi yang dilakukan. Tantangan selanjutnya adalah dari pihak eksternal, yaitu pola pikir masyarakat masih banyak meragukan kinerja perbankan syariah dan menganggap perbankan syariah masih melakukan kegiatan operasional secara konvensional. Sehingga Bank NTB Syariah perlu melakukan sosialisasi dan mengedukasi masyarakat yang bertujuan untuk mengubah pola pikir masyarakat.

\section{Kinerja Bank NTB Syariah Pasca Konversi}

Perkembangan dan pertumbuhan perbankan syariah di Indonesia sudah menjadi salah satu tolak ukur pencapaian atau prestasi atas eksistensi ekonomi syariah. Perkembangan praktik perbankan syariah di Indonesia dari berbagai aspek telah menunjukkan catatan pertumbuhan yang cukup menggembirakan (Nofinawati, 2015). Begitu juga dengan Bank NTB Syariah, selama melakukan konversi menjadi perbankan syariah telah menunjukkan kinerja yang sangat baik. Konversi Bank NTB Syariah telah meningkatkan aset perbankan syariah di Indonesia sebesar 7,26 Triliun rupiah (OJK, 2019).

Tabel Kinerja DPK PT. Bank NTB Syariah

\begin{tabular}{|c|l|r|r|r|r|r|r|}
\hline \multirow{2}{*}{ No } & \multirow{2}{*}{ Produk } & \multicolumn{2}{|c|}{ Des 2018 } & \multicolumn{2}{c|}{ Des 2019 } & \multicolumn{2}{c|}{ Jun-20 } \\
\cline { 3 - 8 } & Nsb & $\begin{array}{c}\text { Nom } \\
\text { (jutaan) }\end{array}$ & Nsb & $\begin{array}{c}\text { Nom } \\
\text { (jutaan) }\end{array}$ & Nsb & $\begin{array}{c}\text { Nom } \\
\text { (jutaan) }\end{array}$ \\
\hline 1 & Giro & 6,447 & 835,301 & 4,178 & 762,192 & 4,574 & $2,095,735$ \\
\hline 2 & Tabungan & 847,040 & $2,391,379$ & 892,747 & $2,541,041$ & 894,047 & $2,091,119$ \\
\hline 3 & Deposito & 3,227 & $1,694,702$ & 3,569 & $3,513,126$ & 3,140 & $4,128,827$ \\
\hline \multicolumn{2}{|c|}{ Total } & $\mathbf{8 5 6 , 7 1 4}$ & $\mathbf{4 , 9 2 1 , 3 8 2}$ & $\mathbf{9 0 0 , 4 9 4}$ & $\mathbf{6 , 8 1 6 , 3 5 9}$ & $\mathbf{9 0 1 , 7 6 1}$ & $\mathbf{8 , 3 1 5 , 6 8 1}$ \\
\hline
\end{tabular}

Sumber: Bank NTB Syariah

Berdasarkan tabel diatas perkembangan Bank NTB Syariah selama beberapa tahun terakhir mengalami peningkatan. Dari seluruh produk DPK Bank NTB Syariah yang dilihat dari jumlah nominal dana mengalami pertumbuhan yang sangat signifikan dengan rata-rata pertumbuhan setiap tahunnya sebesar kurang lebih $40 \%$, namun apabila dilihat dari jumlah nasabah seluruh produk mengalami pertumbuhan yang tidak terlalu signifikan. Padahal pada tahun 2020 merupakan data bulan Juni, namun telah memperlihatkan perkembangan yang sangat dignifikan hanya dalam kurun waktu satu semester. Apabila dikaitkan perkembangan total nasabah dan total nominal dana 
pada setiap tahunnya, dapat dianalisa bahwa pada Bank NTB Syariah mengalami peningkatan kepercayaan dari nasabah dengan mulai menambah nominal tabungan di Bank NTB Syariah, hal ini dibuktikan dengan pertumbuhan jumlah nasabah yang tidak terlalu signifikan namun jumlah nominal dana pada setiap tahunnya mengalami peningkatan yang sangat signifikan.

\section{KESIMPULAN}

Berdasarkan analisis dan pembahasan pada bagian sebelumnya, maka dari penelitian mengenai proses konversi perbankan konvensional menjadi perbankan syariah menyimpulkan bahwa proses konversi Bank NTB Syariah berjalan dengan baik. Manajemen proses dilakukan dengan kehati-hatian dan mempertimbangkan banyak hal dalam pelaksanaan konversi, yaitu persiapan dan pelaksanaan harus secara komprehensif, memprioritaskan pengembangan sumber daya insani (SDI), menjaga performa Bank NTB Syariah tetap baik dan lebih baik, serta mendokumentasikan setiap tahap dengan baik. Pada setiap tahap konversi harus selalu memotivasi SDI yang ada agar tetap berada pada sistem konversi yang diinginkan dengan cara melaksanakan pelatihan secara berkelanjutan baik peningkatan kompetensi maupun perilaku SDI, melakukan Benchmark di perbankan yang sudah memiliki pengalaman dan kinerja yang baik, dan menjalin kerja sama dengan lembagalembaga (konsultan) yang kompeten di bidang konversi perbankan dan pengembangan SDI. Pasca konversi Bank NTB Syariah mengalami peningkatan kinerja yang signifikan, dengan peningkatan potret DPK yang sangat signifikan, yaitu sebesar kurang lebih $40 \%$ rata-rata pertumbuhan setiap tahunnya.

\section{REFERENSI}

Apriyanti, Hani Werdi. 2017. Perkembangan Industri Perbankan Syariah di Indonesia: Analisis Peluang dan Tantangan. MAKSIMUM. 1(1): 16-23.

Bank NTB Syariah. 2020. https://www.bankntbsyariah.co.id.

Tanggal Akses: 15 Januari 2020.

Fadilah, Fitri dan Indri Yuliafitri. 2018. Analisis Efisiensi Bank Umum Syariah Hasil Pemisahan dan Non-Pemisahan Serta Faktor-Faktor yang Mempengaruhinya (Studi pada Bank Umum Syariah yang Terdaftar di Otoritas Jasa Keuangan pada Periode 2011-2016). Jurnal Ekonomi Islam. 9(1): 69-98.

Fanggidae, Roy Stefanus., Dwi Ratmawati dan Tri Siwi Agustina. 2015. Analisis Kesiapan Manajemen Terhadap Implementasi Perubahan Organisasi Pengelolaan SDM
Single Grade di PT Pertamina (Persero) Marketing Operation Region V. Jurnal Manajemen dan Terapan. 1 (8): 55-70.

Handayani, R., dkk. 2018. Pengaruh Religiusitas Terhadap Perilaku Memilih Bank Syariah Melalui Kepercayaan Merek (Studi pada Nasabah Bank Syariah di Kota Mataram). Jurnal Ilmu Manajemen dan Bisnis. 2(6): 47-59.

Islamic Financial Country Index. 2019. Global Islamic Financial Report (GIFRI Award 2019. DDCAP Group.

Kautsar, Sinathrya Al., dkk. 2019. Pengaruh Konversi Bank Konvensional Menjadi Bank Syariah Terhadap Resiko Kebangkrutan Studi Kasus pada Bank Aceh. E-Jurnal Ekonomi dan Bisnis Universitas Udayanan. 8(6): 550-566.

Kementrian Perencanaan Pembangunan Nasional/Badan Perencanaan Pembangunan Nasional. 2018. Masterplan Ekonomi Syariah Indonesia 2019-2024.

Lakonawa, Petrus. 2013. Agama dan Pembentukan Cara Pandang Serta Perilaku Hidup Masyarakat. HUMANIORA. 4(2): 790-799.

Marimin, Agus., Abdul Haris Romdhoni dan Tirta Nur Fitria. 2015. Perkembangan Bank Syariah di Indonesia. Jurnal Ilmiah Ekonomi Islam. 1(2): 75-87.

Mulyadi. 2016. Agama dan Pengaruhnya dalam Kehidupan. Jurnal Tarbiyah Al-Awlad. 6(2): 556-564.

Nofinawati. 2015. Perkembangan Perbankan Syariah di Indonesia. JURIS. 14(2): 168183.

Nurjannah. 2015. Peranan Manajemen Inovasi dalam Meningkatkan Kinerja Organisasi Pendidikan. Conference in Business, Accaunting and Management. 2(1): 27-33.

Otoritas Jasa Keuangan (OJK). 2019. Statistik Perbankan Indonesia. 17(10).

Otoritas Jasa Keuangan (OJK). 2019. Statistik Perbankan Syariah.

Otoritas Jasa Keuangan (OJK). Roadmap Pengembangan Keuangan Syariah Indonesia 2017-2019.

Purba, Asra Idriayanssyah. 2017. Pengaruh Perubahan Bank Umum Syariah Terhadap Minat Menabung di Bank Aceh Syariah pada Masyarakat Kabupaten Aceh Tenggara. Human Falah. 4(1): 72-86.

Putri, Eskasari dan Arief Budhi Dharma. 2016. Analisis Perbedaan Kinerja Keuangan Antara Bank Konvensional dengan Bank Syariah. Riset Akuntansi dan Keuangan Indonesia. 1(2): 98-107.

Rahayuningsih, Idha. 2018. Dinamika Psikologi dalam Perubahan Organisasi. Prosiding 
Seminar Nasional Psikologi UGM. ISBN: 978-602-60885-0-5. 375-384.

Rama, Ali. 2015. Analisis Deskriptif Perkembangan Perbankan Syariah di Asia Tenggara. The Journal of Tauhidinomics. 2(1): 105-123.

Ria, Wati Rahmi. 2004. Konversi Bank Umum Konvensional Menjadi Bank Umum Syariah Berdasarkan UU No. 10 Tahun 1998. Jurnal Hukum dan Pembangunan. 3(34): 268-278.

Samuel, Alvianus K. 2018. Pengaruh Knowledge Management dan Corporate Culture Terhadap Inovasi (Study pada Bank Sulut Cabang Utama Manado). Jurnal EMBA. ISSN 2303-1174. 617-625.

Shafii, Zurina., Shahida Shahimi dan Adel Saaid. 2016. The Factors that Influence the Conversion Proses from Conventional Banks into Islamic Banking in Libyan Conventional Banks: Proposing Conceptual Framework. International Journal of Academic Research in Management and Business. 1(2): 77-87.

Simbolon, Ramli dan Hastin Umi Anisah. Pengaruh Perubahan Organisasi dan Budaya Organisasi Terhadap Kinerja Pegawai (Studi pada Kantor Pelayanan Kekayaan Negara dan Lelang Banjarmasin). Jurnal Wawasan Manajemen. 1(1): 27-38.

Somantri, G. R. 2005. Memahami Metode Kualitatif. Makara, Sosial Humaniora. 9(2): 57-65.

Sunaryo. 2017. Pengaruh Perubahan Organisasi, Budaya Organisasi dan Perilaku Kerja Terhadap Kinerja Karyawan di PT Sisirau Medan. Jurnal Ilmiah Manajemen dan Bisnis. 18(1): 101-114.

Thayib, Balgis., Sri Murni dan Joubert B. Maramis. 2017. Analisis Perbandingan Kinerja Keuangan Bank Syariah dan Bank Konvensional. Jurnal Emba. 5(2): 17591768.

Toin, Dyah Rosna Yustani. 2014. Analisis Kinerja Perbankan (Studi komparasi antara perbankan syariah dan konvensional). Jurnal Siasat Bisnis. 18(2): 202-209.

Wafa, Moh. Ali. 2017. Hukum Perbankan dalam Sistem Operasional Bank Konvensional dan Bank Syariah. KORDINAT. 16(2): 257-270.

Wijaya, Candra. 2017. Perilaku Organisasi. Lembaga Peduli Pengembangan Pendidikan Indonesia (LPPPI), Medan.

Wilardjo, Setia Budhi. 2004. Pengertian, Peranan dan Perkembangan Bank Syariah di Indonesia. VALUE ADDED. 2(1): 1-10.

Zuhirsyan, Muhammad dan Nurlinda. 2018. Pengaruh Religiusitas dan Persepsi
Nasabah Terhadap Keputusan Memilih Bank Syariah. Al-Amwal. 1(10): 48-62. 